\title{
ENGINEERING
}

\section{Analysis of axisymmetric bending of round continuous plates on a variable elastic base by the finite element method}

\author{
Y. Krutii 1,a, M. Surianinov 1,b*, M. Soroka ${ }^{1, \mathrm{c}}$, G. Karnauhova ${ }^{1, \mathrm{~d}}$ \\ ${ }^{1}$ Odessa State Academy of Civil Engineering and Architecture, 4, Didrihsona str., Odessa, Ukraine, 65029 \\ Corresponding author: ${ }^{\mathrm{b}} \mathrm{sng} @$ ogasa.org.ua
}

Paper received 01.06.20; Accepted for publication 18.06.20.

\section{https://doi.org/10.31174/SEND-NT2020-244VIII30-04}

\begin{abstract}
The results of the study of axisymmetric bending of round continuous plates on a variable elastic foundation are presented. The finite element method used in the LIRA-SAPR software is used as the most universal of the numerical methods. Eight options for calculating a continuous round plate (slab) under two fixing conditions and two different laws of changing the coefficient of subgrade resistance are considered. In all cases, the results completely coincide with the known results of bending plates that do not have an elastic foundation and in the case when this foundation exists and its resistance is constant. It is noted that the discrepancy here is very slight - in the third significant digit after the decimal point for deflection at simple support and in the second for moments. With fixing, deflections and moments also differ from the corresponding values of the known solutions in the second significant digit after the decimal point. As for the elastic foundation, coefficient of subgrade resistance of which varies according to the law of a curved parabola, there are no data for comparison; need an alternative method that will allow you to perform similar calculations. To date, such a method (analytical) has already been developed by the authors of the paper. Its concept and comparison with the results of finite element analysis will be the subject of our next publication in the field of calculation of plates on a variable elastic foundation.
\end{abstract}

Keywords: plate, elastic foundation, Winkler foundation, coefficient of subgrade resistance, finite element method, LIRA-SAPR.

Introduction. A plate on an elastic foundation is a design scheme for many structures used in various industries. First of all, this applies to construction projects, and, in particular, to foundation beams and slabs. The study of structures lying on an elastic foundation is one of the urgent and most complex problems of the mechanics of a deformable solid. Recently, interest in these tasks has been growing more and more in connection with the transition to the construction of multi-storey buildings. In design practice, one has to deal with cases when the design for one reason or another does not fully rely on an elastic foundation. For example, the presence of underground utilities, soil erosion as a result of pipeline accidents, karst formations in the construction zone of the object. In these cases, an elastic bed model with a variable bed coefficient is used. There are various models of elastic foundation. The simplest is the Winkler model, or spring model. For beams on a permanent elastic foundation, this model allows you to get the exact solution, but for slabs no. When the elastic foundation is variable, the task becomes even more complicated. There is no single approach to a universal analytical solution construction. Therefore, approximate calculation methods based on the discretization of the system are used.

Problem formulation. The variable bed coefficient model allows you to take into account the heterogeneous properties of the base, both in plan and in depth. Such a model, for example, is used in calculating the stress-strain state of the foundations of structures lying on subsidence soils. In this case, the coefficient of bed is a variable, depending on the coordinate in which the settlement of the base is determined. Differential equations describing the behavior of such structures under different types of exposure are equations with variable coefficients, the analytical solutions of which are extremely rare in scientific publications.

In this paper, in the general case, an annular plate of constant cylindrical stiffness is considered, which lies on a variable elastic foundation and is under the action of a continuously distributed transverse load.

Analysis of publications. The theory of calculating struc- tures lying on an elastic foundation with one or two bed coefficients was developed in the works of A.N. Krylov, M.N. Gersevanov, P.L. Pasternak, V.Z. Vlasov, B.N. Zhemochkin, I.A. Simvulidi [1] and many others. Among foreign scientists, O.C. Zienkiewicz [2], C.S. Desai, J.T. Christian, A.M. Ioannides etc. had worked on this problem.

The problem of calculating a rectangular slab on an elastic foundation has so far not had an exact analytical solution [3] even for the simplest model of an elastic foundation (Winkler model). The main problem here is to satisfy the static boundary conditions at the edges of the slab. For the problem of axisymmetric bending of round plates on an elastic foundation, a solution is proposed by representing the sediment of the plate in the form of the eigenfunctions of the differential operator of the axisymmetric vibrations of a round plate with free faces. This solution is implemented when solving contact problems for ring plates $[4,5]$.

The dynamics of round plates on an elastic foundation, based on the classical theory of plates, has been studied by many researchers [6-8]. In these works, results were obtained for practical applications based on analytical and numerical solutions. However, most of the work is associated with a variable thickness of the plate with constant resistance of the elastic base.

The natural vibrations of a round plate lying on a variable elastic foundation of the Winkler type were considered in the work of A.M. Doronin and V.A. Soboleva [9]. The coefficient of the bed base varies according to a power law in the direction of the radius. The natural frequencies of oscillations are determined by the Kirchhoff theory by the analytical method. The basic equation written in complex variables is solved by the method of successive approximations. Calculations for the coefficient of the bed are carried out; it varies according to a linear or quadratic law.

In article [10], free linear transverse vibrations of a circular plate basing on an elastic Winkler-type foundation are considered. A constant radial load acts on the plate. The natural frequencies of the plate are determined depending on the load parameter and the Winkler constant by numerically 
solving the characteristic equation. The existence of an additional oscillation frequency, which depends only on the Winkler constant, is established.

In [11], a model was proposed based on the Winkler theory, but with a variable bed coefficient, which allows one to take into account the inhomogeneous behavior of the foundation. The basic equation is solved using the Galerkin method and the possibility of the presence of hard points in the foundation is considered.

Aim of Paper. The aim of this work is to study the axisymmetric bending of round continuous plates on a variable elastic foundation using the finite element method.

Materials and Methods. Eight calculation options were considered - four for a steel round plate and four more for a concrete round plate under two conditions of support and two different laws of changing the coefficient of bed. To solve this problem, the finite element method implemented in the LIRA-SAPR software [12] is used as the most universal of numerical methods.

Research Results. In the general case, an annular plate of constant cylindrical stiffness is considered (Fig. 1), which lies on a variable elastic foundation and is under the action of a continuously distributed transverse load. Axially symmetric plate bending occurs when acting loads, $q(r)$ elastic foundation reaction $R(r)$ and the conditions for fixing the edges are not dependent on the polar angle $\theta$. With such a bend in the plate, only three internal forces act, namely, the

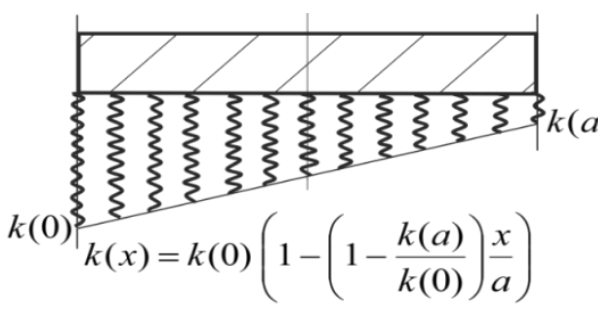

radial $M_{r}$ and circular $M_{\theta}$ bending moments, as well as radial transverse force $Q_{r}$.

Here $a$ and $b-$ radii of the outer and inner contour circles of the plate, $r-$ radial coordinate $(0 \leq r \leq a)$. In the particular case, with the value $b=0$, we will get a solid round plate.

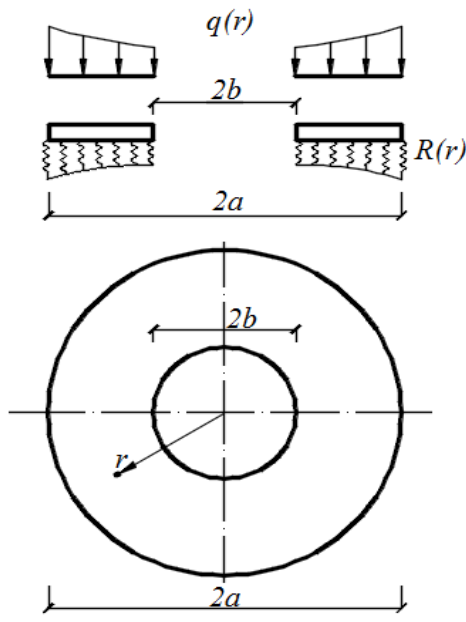

Fig. 1. Plate on a variable elastic foundation under transverse loading

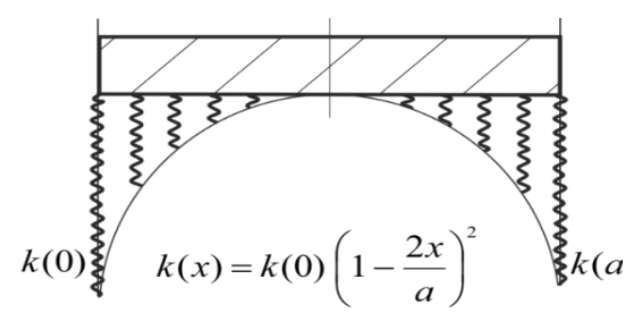

Fig. 2. Foundation models

Table 1. Deflections and moments at various coefficients of the bed in a concrete slab with simple support

\begin{tabular}{|c|c|c|c|c|c|c|}
\hline \multirow{3}{*}{ Coord., m } & \multicolumn{2}{|c|}{$w, \mathrm{~mm}$} & \multicolumn{2}{|c|}{$M_{r}, \mathrm{kNm} / \mathrm{m}$} & \multicolumn{2}{|c|}{$M_{\theta}, \mathrm{kNm} / \mathrm{m}$} \\
\hline & \multicolumn{6}{|c|}{ The law of changing the coefficient of bed } \\
\hline & Linear & Concave parabola & Linear & Concave parabola & Linear & Concave parabola \\
\hline 0 & $-0,003947$ & $-0,06593$ & $-0,017122$ & 0,487252 & $-0,017271$ & 0,492283 \\
\hline 0,085714 & $-0,003976$ & $-0,06509$ & $-0,016508$ & 0,451607 & $-0,017036$ & 0,48059 \\
\hline 0,171429 & $-0,004063$ & $-0,06264$ & $-0,016825$ & 0,3775 & $-0,016854$ & 0,455318 \\
\hline 0,257143 & $-0,004206$ & $-0,05877$ & $-0,019370$ & 0,278165 & $-0,017164$ & 0,419495 \\
\hline 0,342857 & $-0,004410$ & $-0,05378$ & $-0,024670$ & 0,165684 & $-0,018200$ & 0,375868 \\
\hline 0,428571 & $-0,004687$ & $-0,04804$ & $-0,032596$ & 0,052837 & $-0,020062$ & 0,327456 \\
\hline 0,514286 & $-0,005062$ & $-0,04193$ & $-0,042260$ & $-0,04885$ & $-0,022710$ & 0,277306 \\
\hline 0,6 & $-0,005564$ & $-0,03582$ & $-0,051884$ & $-0,13063$ & $-0,025949$ & 0,228202 \\
\hline 0,685714 & $-0,006227$ & $-0,03003$ & $-0,058716$ & $-0,18743$ & $-0,029408$ & 0,182436 \\
\hline 0,771429 & $-0,007079$ & $-0,02479$ & $-0,059111$ & $-0,21796$ & $-0,032537$ & 0,141674 \\
\hline 0,857143 & $-0,008134$ & $-0,02025$ & $-0,048889$ & $-0,22419$ & $-0,034619$ & 0,106912 \\
\hline 0,942857 & $-0,009376$ & $-0,01647$ & $-0,024044$ & $-0,21034$ & $-0,034830$ & 0,078531 \\
\hline 1,028571 & $-0,010747$ & $-0,01343$ & 0,018185 & $-0,18162$ & $-0,032336$ & 0,056408 \\
\hline 1,114286 & $-0,012131$ & $-0,01106$ & 0,077986 & $-0,14314$ & $-0,026437$ & 0,04007 \\
\hline 1,2 & $-0,013354$ & $-0,00925$ & 0,151624 & $-0,09911$ & $-0,016745$ & 0,028851 \\
\hline 1,285714 & $-0,014186$ & $-0,00786$ & 0,230399 & $-0,05268$ & $-0,003373$ & 0,022016 \\
\hline 1,371429 & $-0,014365$ & $-0,00672$ & 0,300330 & $-0,00643$ & 0,012910 & 0,018835 \\
\hline 1,457143 & $-0,013633$ & $-0,00567$ & 0,342984 & 0,036187 & 0,030580 & 0,018572 \\
\hline 1,542857 & $-0,011792$ & $-0,00458$ & 0,337644 & 0,068602 & 0,047384 & 0,020383 \\
\hline 1,628571 & $-0,008776$ & $-0,0033$ & 0,264739 & 0,078045 & 0,060494 & 0,023101 \\
\hline 1,714286 & $-0,004716$ & $-0,00176$ & 0,110008 & 0,042321 & 0,066801 & 0,024939 \\
\hline 1,8 & 0,0000 & 0,0000 & 0,0000 & 0,0000 & 0,067324 & 0,025409 \\
\hline
\end{tabular}




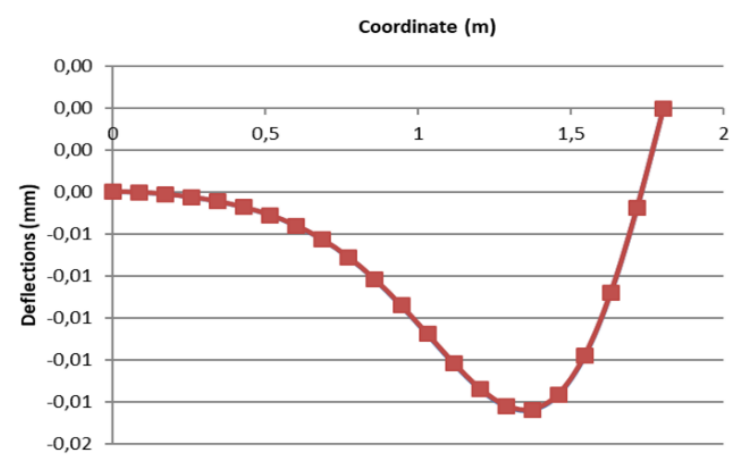

Fig. 3. Dependence of the deflection on the coordinate with a linear coefficient of bed

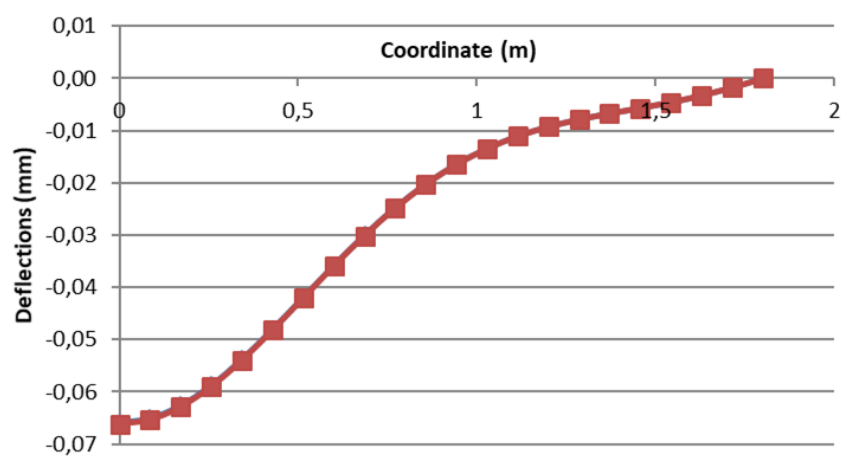

Fig. 4. Dependence of the deflection on the coordinate with the coefficient of bed, which varies according to the law of concave parabola

Table 2. Deflections and moments at different bed coefficients in a concrete slab with rigid contour fixing

\begin{tabular}{|c|c|c|c|c|c|c|}
\hline \multirow{3}{*}{ Coord., m } & \multicolumn{2}{|c|}{$w, \mathrm{~mm}$} & \multicolumn{2}{|c|}{$M_{r}, \mathrm{kNm} / \mathrm{m}$} & \multicolumn{2}{|c|}{$M_{\theta}, \mathrm{kNm} / \mathrm{m}$} \\
\hline & \multicolumn{6}{|c|}{ The law of changing the coefficient of bed } \\
\hline & Linear & Concave parabola & Linear & Concave parabola & Linear & $\begin{array}{l}\text { Concave } \\
\text { parabola }\end{array}$ \\
\hline 0 & $-0,003925$ & $-0,003690$ & $-0,021528$ & $-0,003661$ & $-0,021650$ & $-0,003579$ \\
\hline 0,085714 & $-0,003962$ & $-0,003696$ & $-0,021064$ & $-0,004276$ & $-0,021467$ & $-0,003778$ \\
\hline 0,171429 & $-0,004071$ & $-0,003716$ & $-0,021460$ & $-0,005715$ & $-0,021353$ & $-0,004240$ \\
\hline 0,257143 & $-0,004252$ & $-0,003752$ & $-0,023511$ & $-0,008026$ & $-0,021642$ & $-0,004973$ \\
\hline 0,342857 & $-0,004509$ & $-0,003811$ & $-0,027095$ & $-0,011263$ & $-0,022429$ & $-0,005996$ \\
\hline 0,428571 & $-0,004852$ & $-0,003902$ & $-0,031339$ & $-0,015303$ & $-0,023649$ & $-0,007310$ \\
\hline 0,514286 & $-0,005295$ & $-0,004039$ & $-0,034671$ & $-0,019683$ & $-0,025088$ & $-0,008871$ \\
\hline 0,6 & $-0,005850$ & $-0,004236$ & $-0,034902$ & $-0,023436$ & $-0,026395$ & $-0,010564$ \\
\hline 0,685714 & $-0,006525$ & $-0,004506$ & $-0,029432$ & $-0,024991$ & $-0,027100$ & $-0,012179$ \\
\hline 0,771429 & $-0,007311$ & $-0,004860$ & $-0,015646$ & $-0,022198$ & $-0,026657$ & $-0,013398$ \\
\hline 0,857143 & $-0,008176$ & $-0,005295$ & 0,008444 & $-0,012606$ & $-0,024504$ & $-0,013805$ \\
\hline 0,942857 & $-0,009056$ & $-0,005792$ & 0,043340 & 0,005936 & $-0,020166$ & $-0,012926$ \\
\hline 1,028571 & $-0,009849$ & $-0,006302$ & 0,087085 & 0,034312 & $-0,013374$ & $-0,010316$ \\
\hline 1,114286 & $-0,010421$ & $-0,006745$ & 0,134376 & 0,070885 & $-0,004206$ & $-0,005686$ \\
\hline 1,2 & $-0,010615$ & $-0,007010$ & 0,176028 & 0,110209 & 0,006783 & 0,000930 \\
\hline 1,285714 & $-0,010275$ & $-0,006965$ & 0,199085 & 0,142109 & 0,018468 & 0,009007 \\
\hline 1,371429 & $-0,009288$ & $-0,006485$ & 0,187797 & 0,151674 & 0,029123 & 0,017386 \\
\hline 1,457143 & $-0,007630$ & $-0,005496$ & 0,125536 & 0,120643 & 0,036490 & 0,024224 \\
\hline 1,542857 & $-0,005425$ & $-0,004030$ & $-0,002570$ & 0,030360 & 0,037943 & 0,027074 \\
\hline 1,628571 & $-0,002995$ & $-0,002291$ & $-0,206942$ & $-0,134215$ & 0,030741 & 0,023121 \\
\hline 1,714286 & $-0,000907$ & $-0,000713$ & $-0,491704$ & $-0,380818$ & 0,012317 & 0,009540 \\
\hline 1,8 & 0,000000 & 0,000000 & $-0,662781$ & $-0,533254$ & 0,000000 & 0,000000 \\
\hline
\end{tabular}

Geometrical and finite element modeling of the plate was performed in the LIRA-SAPR software. Based on this model, we consider a series of problems with various sets of input data. Namely: we will consider two plates made of various materials with simple support along the contour, and then the same plates rigidly fixed along the contour.

The calculations for each of them will be performed with two models of the elastic base - with the bed coefficient changing according to the linear law and according to the law of the concave parabola (Fig. 2).

Example 1. Concrete plate with contour simple support.

As a first example, consider a round plate with a thickness of $h=0,12 m$ and radius of $a=1,8 m$, which is under the action of a uniformly distributed load $q=15 \mathrm{kPa}$. Material - concrete $\left(E=1,5 \cdot 10^{7} \mathrm{kPa} ; \mu=\mathrm{O}\right)$.

Calculation results with the linear law of change in the coefficient of bed and with the concave parabola changing law are given in Table 1.

Figure 3 shows the dependence of the deflection on the coordinate for a concrete slab simply supported along the contour and basing on a foundation, the bed coefficient of which varies linearly, and Figure 4 is for the same plate, but basing on a foundation, the bed coefficient of which varies according to the law of a concave parabola.

Example 2. Concrete plate with the same initial data as in the previous example, but with rigid fixing along the contour.

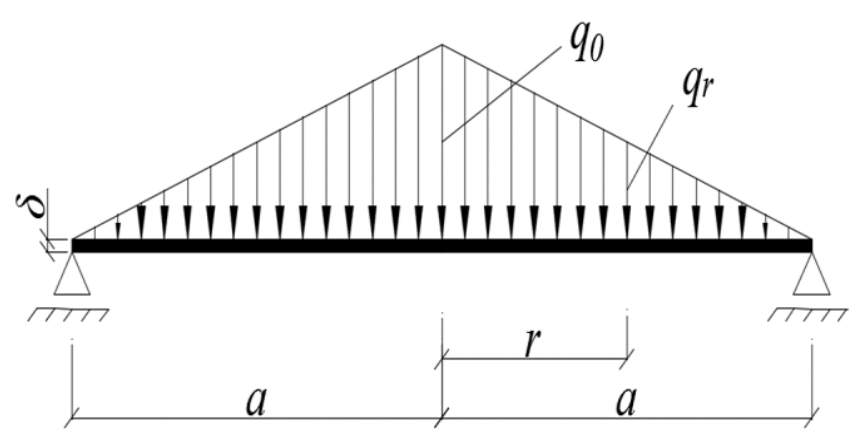

Fig. 5. Load varying along the radius linearly

Calculation results with the linear law of change in the coefficient of bed and with the concave parabola changing law are given in Table 2.Example 3. Steel plate with the contour simple support. 
Table 3. Deflections and moments at various bed coefficients in a simply supported steel plate

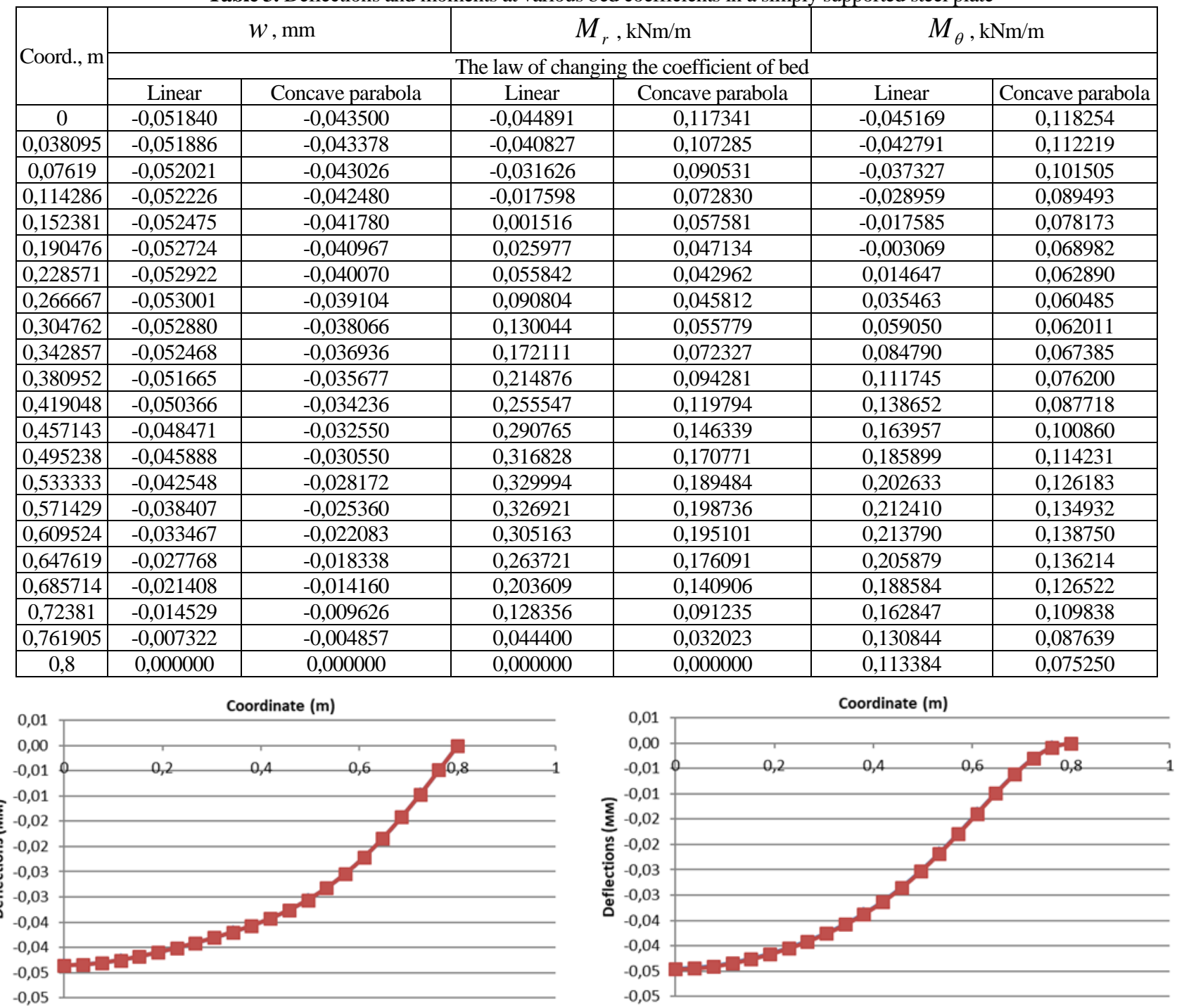

Fig. 6. Dependence of the deflection on the coordinate with a linear

Fig. 7. Dependence of the deflection on the coordinate with the coefficoefficient of bed cient of bed, which varies according to the law of concave parabola

Table 4. Deflections and moments at various ratios of the bed in a rigidly fixed steel plate

\begin{tabular}{|c|c|c|c|c|c|c|}
\hline \multirow{2}{*}{ Coord., $\mathrm{m}$} & \multicolumn{3}{|c|}{$w, \mathrm{~mm}$} & \multicolumn{2}{c|}{$M_{r}, \mathrm{kNm} / \mathrm{m}$} & \multicolumn{2}{c|}{$M_{\theta}, \mathrm{kNm} / \mathrm{m}$} \\
\cline { 2 - 7 } & \multicolumn{7}{|c|}{ The law of changing the coefficient of bed } \\
\cline { 2 - 7 } & Linear & Concave parabola & Linear & Concave parabola & Linear & Concave parabola \\
\hline 0 & $-0,053638$ & $-0,044528$ & $-0,002481$ & 0,127336 & $-0,003049$ & 0,128078 \\
\hline 0,038095 & $-0,053641$ & $-0,044396$ & 0,005254 & 0,119488 & 0,001502 & 0,123348 \\
\hline 0,07619 & $-0,053642$ & $-0,044012$ & 0,022031 & 0,107524 & 0,011562 & 0,115508 \\
\hline 0,114286 & $-0,053609$ & $-0,043401$ & 0,046279 & 0,096754 & 0,026262 & 0,107696 \\
\hline 0,152381 & $-0,053492$ & $-0,042592$ & 0,077054 & 0,090180 & 0,045085 & 0,101706 \\
\hline 0,190476 & $-0,053223$ & $-0,041603$ & 0,113105 & 0,089543 & 0,067398 & 0,098674 \\
\hline 0,228571 & $-0,052720$ & $-0,040443$ & 0,152660 & 0,095415 & 0,092333 & 0,099139 \\
\hline 0,266667 & $-0,051890$ & $-0,039101$ & 0,193303 & 0,107310 & 0,118722 & 0,103097 \\
\hline 0,304762 & $-0,050636$ & $-0,037553$ & 0,231885 & 0,123724 & 0,145048 & 0,110020 \\
\hline 0,342857 & $-0,048861$ & $-0,035758$ & 0,264527 & 0,142172 & 0,169438 & 0,118884 \\
\hline 0,380952 & $-0,046482$ & $-0,033673$ & 0,286742 & 0,159256 & 0,189701 & 0,128192 \\
\hline 0,419048 & $-0,043436$ & $-0,031249$ & 0,293655 & 0,170775 & 0,203421 & 0,136026 \\
\hline 0,457143 & $-0,039696$ & $-0,028452$ & 0,280355 & 0,171945 & 0,208090 & 0,140134 \\
\hline 0,495238 & $-0,035278$ & $-0,025266$ & 0,242347 & 0,157748 & 0,201313 & 0,138076 \\
\hline 0,533333 & $-0,030264$ & $-0,021713$ & 0,176093 & 0,123444 & 0,181032 & 0,127431 \\
\hline 0,571429 & $-0,024796$ & $-0,017860$ & 0,079588 & 0,065214 & 0,145785 & 0,106078 \\
\hline 0,609524 & $-0,019101$ & $-0,013833$ & $-0,047097$ & $-0,019097$ & 0,094954 & 0,072505 \\
\hline 0,647619 & $-0,013475$ & $-0,009823$ & $-0,201398$ & $-0,129267$ & 0,028977 & 0,026142 \\
\hline 0,685714 & $-0,008297$ & $-0,006091$ & $-0,378028$ & $-0,262094$ & $-0,050521$ & $-0,032362$ \\
\hline 0,72381 & $-0,004000$ & $-0,002957$ & $-0,569023$ & $-0,411126$ & $-0,140685$ & $-0,100960$ \\
\hline 0,761905 & $-0,001068$ & $-0,000795$ & $-0,764192$ & $-0,566905$ & $-0,237571$ & $-0,176239$ \\
\hline 0,8 & 0,000000 & 0,0000 & $-0,863413$ & $-0,64632$ & $-0,287804$ & $-0,21544$ \\
\hline
\end{tabular}


As a third example we will consider round plate with a thickness of $h=0,03 m$ and radius $a=0,8 m$, which is under action of load, changing along radius by linear law $q=q_{\mathrm{o}}\left(1-\frac{r}{a}\right)$, where $q_{\mathrm{o}}=200 k P a-$ load intensity in the center of the plate (Fig. 5). Material - steel ( $\left.E=2,1 \cdot 10^{8} \mathrm{kPa} ; \mu=0,33\right)$.

Calculation results with the linear law of change in the coefficient of bed and with the concave parabola changing law are given in Table 3.

Example 4. Steel plate with the same initial data as in previous example, but rigidly fixed along contour.

Calculation results with the linear law of change in the coefficient of bed and with the concave parabola changing law are given in Table 4.

Figure 6 shows the dependence of the deflection on the coordinate for a steel plate simply supported along the contour and basing on a foundation, the bed coefficient of which varies linearly, and Figure 7 is for the same plate, but rigidly fixed along contour.

Conclusions. Thus, using the most universal of the numerical methods - the finite element method - eight options for calculating a continuous round plate (slab) lying on an elastic Winkler-type foundation are considered under two fixing conditions and two different laws of changing the bed coefficient. Modeling and calculations are performed using the LIRA-SAPR software package. In all cases, the results completely coincide with the known results of bending plates that do not have an elastic base and in the case when this base exists and its resistance is constant [13]. The discrepancy here is very slight - in the third significant digit after the decimal point for deflection with simple support and in the second for moments. With rigid fixing, deflections and moments also differ from the corresponding values of the known solutions in the second significant digit after the decimal point. As for the elastic foundation, the bed coefficient of which varies according to the law of a curved parabola, there are no data for comparison; need an alternative method that will allow you to perform similar calculations. To date, such a method (analytical) has already been developed by the authors of the article. Its concept and comparison with the results of finite element analysis will be the subject of our next publication in the field of calculation of plates on a variable elastic base.

\section{ЛИТЕРАТУРА}

1. Симвулиди И.А. Расчет инженерных конструкций на упругом основании. Изд. 3-е, испр. и доп. Учебное пособие для вузов// М., «Высш. школа», 1973. 431 с.

2. Zienkiewich, O.C., Taylor, R.L. The Finite Element Method for Solid and Structural Mechanics// Oxford: ButterworthHeinemann, 2005. 736 p.

3. Босаков С.В. К расчету прямоугольных плит на упругом основании// Вестник БНТУ, № 5, 2007, С. 5-10.

4. Цейтлин А.И. Прикладные методы решения краевых задач строительной механики// М.: Стройиздат, 1984. 334 с.

5. Босаков С.В. Метод Ритца в контактных задачах теории упругости// Брест, 2006. 108 с.

6. Leissa, A.W. Vibration of Plates// NASA Report No. SP, 1969, $160 \mathrm{p}$.

7. Volterra E.C. Dynamics of vibrations// Charles E. Merrill Books, Incorporated, 1965. $622 \mathrm{p}$.

8. Wang, Jt. Free vibration of stepped circular plates on elastic foundations// J. of Sound and Vibration. 1992. V. 159. № 1. P.

175-181.

9. Доронин А.М., Соболева В.А. Собственные колебания круглой пластинки, лежащей на переменном упругом основании типа Винклера// Вестник Нижегородского университета им. Н.И. Лобачевского, № 4 (1). 2014. С. 254-258.

10. Kurktchiev, R., Vaisilov, I. Vibration of circular plates on elastic foundation with in-plane loading// J. of Theor. and Appl. Mech. Sofia. 1994-95. V. XXV. № 1-2. P. 27-33.

11. Mofid, M., Noroozi, M. A plate on Vinkler foundation with variable coefficient// Transaction A: Civil Engineering. 2009. V. 16. № 3. Р. 249-255.

12. Городецкий Д.А., Барабаш М.С., Водопьянов Р.Ю. и др. Программный комплекс ЛИРА-САПР 2015. Учебное пособие; под ред. академика РААСН А.С. Городецкого. М., 2015. $376 \mathrm{c}$.

13. Вайнберг Д.В. Вайнберг Е.Д. Расчет пластин// К: Будівельник, $1970.436 \mathrm{c}$.

\section{REFERENCES}

1. Simvulidi, I.A. Raschet inzhenernykh konstrukczij na uprugom osnovanii. Izd. 3-e, ispr. i dop. Uchebnoe posobie dlya vuzov. M.: Vy'ssh. shkola, 1973, 431p.

3. Bosakov, S.V. K raschetu pryamougol'nykh plit na uprugom osnovanii// Vestnik BNTU, 5, 2007, 5-10.

4. Czejtlin, A.I. Prikladnye metody resheniya kraevykh zadach stroitelnoj mekhaniki// M.: Strojizdat, 1984, 334p.

5. Bosakov, S.V. Metod Ritcza v kontaktnykh zadachakh teorii uprugosti// Brest, 2006, 108p.
9. Doronin, A.M., Soboleva, V.A. Sobstvennye kolebaniya krugloj plastinki, lezhashhej na peremennom uprugom osnovanii tipa Vinklera// Vestnik Nizhegorodskogo universiteta im. N.I. Lobachevskogo, 2014. 4 (1), 254-258.

12. Gorodeczkij, D.A., Barabash, M.S., Vodop'yanov, R.Yu. i dr. Programmny'j kompleks LIRA-SAPR 2015. Uchebnoe posobie, pod red. akademika RAASN A.S. Gorodeczkogo, 2015. 376. Budi'vel'nik, 1970. 436.
13. Vajnberg, D.V., Vajnberg, E.D. Raschet plastin// K: 